\title{
KAJIAN TEKNIS PENERAPAN MATERIAL SANDWICH PADA STRUKTUR LAMBUNG KAPAL TANKER
}

\author{
Abdi Ismail \\ Program Studi Permesinan Kapal, Fakultas Vokasi, Universitas Pertahanan Republik Indonesia, \\ Kabupaten Belu, Indonesia \\ *E-mail korespondensi: abdiismail1993@gmail.com
}

\begin{abstract}
ABSTRAK
Kajian teknis berupa analisis kekuatan dan berat struktur antara struktur lambung konvensional dan lambung dengan material sandwich dilakukan pada kapal tanker 17500 DWT menggunakan metode elemen hingga. Fiberglass reinforced polyurethane elastomer (FRPU) digunakan sebagai core dari material sandwich kapal tanker dan baja digunakan sebagai material dari faceplate. Pada model struktur lambung konvensional tegangan maksimum yang terjadi adalah $83.5 \mathrm{MPa}$, sedangkan model struktur lambung sandwich menghasilkan tegangan maksimum sebesar 84.5 $M P a$. Struktur lambung konvensional maupun struktur lambung material sandwich memenuhi kriteria, karena kedua model memiliki tegangan jauh dibawah batas tegangan yang diizinkan yaitu $235 \mathrm{MPa}$. Selain itu, penerapan material sandwich menghasilkan kenaikan tegangan yang sangat kecil, yaitu sebesar 1 MPa atau setara dengan 1.2\%, tetapi menghasilkan pengurangan berat sebesar 3 ton atau $6.2 \%$ dibandingkan dengan struktur konvensional. Penerapan material sandwich dapat mengurangi berat konstruksi kapal, sehingga tanker dapat mengangkut muatan lebih banyak dan operasional kapal dalam sekali perjalanan akan lebih ekonomis. Dengan demikian, pengembangan material ringan kapal diharapkan mampu menunjang kualitas operasional kapal dan diharapkan mampu meningkatkan daya saing kapal tanker nasional.
\end{abstract}

Kata Kunci: struktur ringan kapal, material sandwich, analisis kekuatan, struktur lambung, kapal tanker.

\begin{abstract}
Technical studies in structural strength and weight analysis between the conventional hull structure and the hull with sandwich material were carried out on a 17500 DWT tanker using the finite element method. Fiberglass reinforced polyurethane elastomer (FRPU) is used as the core of the tanker sandwich material, and steel is used as the material for the faceplate. In the conventional model, the maximum stress occurring is $83.5 \mathrm{MPa}$, while the sandwich model produces maximum stress of $84.5 \mathrm{MPa}$. The conventional hull structure and the sandwich material hull structure meet the criteria because both models have stresses far below the allowable stress limit of $235 \mathrm{MPa}$. The application of sandwich material results in a minimal stress increase of $1 \mathrm{MPa}$ or equivalent to 1.2\%. Still, it results in a weight reduction of 3 tons or $6.2 \%$ compared to conventional structures. The application of the sandwich plate can reduce the weight of the ship's construction so that the tanker can carry more cargo, and the operation of the ship in one trip will be more economical. Thus, the development of lightweight ship materials is expected to support the operational quality of ships and is expected to increase the competitiveness of national tankers.
\end{abstract}

Keywords: ship light structure, sandwich material, strength analysis, hull structure, tanker. 


\section{PENDAHULUAN}

Pengembangan teknologi material kapal mengarah pada pengembangan material ringan, dimana struktur yang diharapkan adalah ringan dan cukup kuat. Material sandwich dikembangkan oleh para peneliti untuk menjawab tantangan tersebut. Material sandwich terdiri dari dua bagian yaitu faceplate dan core. Faceplate dibuat dari material yang memiliki kekakuan yang tinggi. Sedangkan core dibuat dari material yang memiliki kekakuan dan densitas lebih rendah, sehingga diperoleh material sandwich yang memiliki kekakuan relatif tinggi dengan berat yang rendah (Mohamed et al., 2015; Yang et al., 2016).

Material sandwich telah diaplikasikan pada industri perkapalan internasional. Material sandwich memberikan konstruksi yang lebih baik, proses fabrikasinya lebih mudah (Ramakrishnan \& Kumar, 2016), dan dapat mengurangi kebutuhan penegar pada konstruksi kapal (Sujiatanti et al., 2018) sehingga penerapan material sandwich dapat meningkatkan pemanfaatan ruang pada kapal.

Material sandwich pada kapal telah dilakukan berbagai penelitian sebelumnya. Ardhyananta et al (2019) telah melakukan karakterisasi bioresin untuk bagian core dari konstruksi kapal material sandwich. Deteksi kerusakan pada material sandwich dengan indikator kerusakan berupa frekuensi natural (Ariesta et al., 2021a; Ariesta et al., 2021b, Ismail et al., 2018; Ismail et al., 2020) dan analisis modal dinamis (Tuswan et al., 2021a; Tuswan et al., 2022) juga telah dilakukan. Aplikasi material sandwich pada stuktur kapal telah dilakukan oleh Brooking \& Kennedy (2004). Berdasarkan studi numerik tersebut didapatkan bahwa tegangan pada konstruksi pelat datar kapal yang menggunakan material sandwich memiliki nilai lebih kecil dari tegangan izin (Brooking \& Kennedy, 2004).

Komposisi material core untuk struktur kapal berupa bioresin (Ardhyananta et al., 2019; Tuswan et al., 2021b) dan unsaturated polyester resin (Tuswan et al., 2021a) telah dikembangkan. Tetapi faceplate baja dan core yang terbuat dari polyurethane elastomer (PU) adalah konfigurasi yang lebih banyak digunakan pada material sandwich kapal (Ramakrishnan \& Kumar, 2016). Lebih khusus, material sandwich yang telah komersial digunakan untuk kapal adalah Sandwich Plate System (SPS). SPS menggunakan material faceplate yang terbuat dari baja dan material core yang terbuat dari room temperature cured polyurethane elastomer (RTC PU). RTC PU memiliki harga yang relatif mahal dan tidak mudah tersedia di beberapa negara, termasuk Indonesia (Ismail et al., 2021a; Ismail et al., 2021b; Ismail et al., 2021c).

Sedangkan casting polyurethane elastomer memiliki harga lebih murah dan lebih familiar digunakan atau lebih banyak tersedia di banyak negara termasuk negara berkembang seperti Indonesia. Material yang murah dan mudah didapatkan menjadi kriteria dalam pemilihan material core dari material sandwich kapal. Material core yang lebih ekonomis bisa diperoleh dengan mengkombinasikan casting polyurethane elastomer dengan fiberglass, sehingga didapatkan fiberglass reinforced polyurethane elastomer (FRPU).

Pada penelitian simulasi numerik ini, FRPU digunakan sebagai core dari material sandwich kapal tanker. Kajian teknis berupa analisis kekuatan serta berat struktur dari konstruksi sisi lambung kapal konvensional akan dibandingkan dengan konstruksi sisi lambung kapal yang telah menggunakan material sandwich. Hal ini dilakukan untuk mengetahui sejauhmana manfaat dari penerapan material sandwich pada konstruksi sisi lambung kapal tanker menggunakan metode elemen hingga.

\section{BAHAN DAN METODE}

Kajian perbandingan penerapan material baja konvensional dan material sandwich di struktur sisi lambung kapal dilakukan pada kapal tanker 17500 DWT untuk mengetahui perbedaan kekuatan dan pengurangan berat struktur akibat penerapan material sandwich menggunakan metode elemen hingga. Kekuatan struktur dikaji melalui variabel tegangan, semakin kuat sebuah struktur menahan suatu beban, maka tegangan nya akan semakin kecil. Sebuah struktur tidak layak ketika struktur tersebut diberikan beban dan menghasilkan tegangan melebihi tegangan izin sebuah standard tertentu. Tegangan izin biasa dikembangkan berdasarkan variabel tegangan luluh (yield stress atau yield strength) suatu material. 
Ukuran utama kapal tanker dapat dilihat pada Tabel 1, sedangkan sifat material dari baja pada bagian faceplate dan FRPU pada bagian core dapat dilihat pada Tabel 2. FRPU tersebut memiliki massa jenis sebesar $1098 \mathrm{~kg} / \mathrm{m}^{3}$, ultimate tensile strength sebesar $21 \mathrm{MPa}$, elongation at break sebesar 47\%, dan hardness sebesar 66 shore-D, sehingga PU tersebut memenuhi standard Lloyd's Register untuk diterapkan sebagai core dari material sandwich kapal (Lloyd's Register, 2020).

Tabel 1. Ukuran utama kapal tanker

\begin{tabular}{lrl}
\hline \multicolumn{1}{c}{ Variabel } & Dimensi & \multicolumn{1}{c}{ Satuan } \\
\hline Displacement & 17.500 & DWT \\
Length Overall (LOA) & 157,5 & $\mathrm{~m}$ \\
Length Perpendicular (LPP) & 149,5 & $\mathrm{~m}$ \\
Breath Moulded (B) & 27,7 & $\mathrm{~m}$ \\
Depth Moulded & 12 & $\mathrm{~m}$ \\
Draft $(\mathrm{T})$ & 7 & $\mathrm{~m}$ \\
Service Speed (Vs) & 13 & $\mathrm{knots}$ \\
Complement & 28 & Orang \\
\hline
\end{tabular}

Tabel 2. Sifat material baja dan FRPU

\begin{tabular}{cccc}
\hline Material & $\begin{array}{c}\text { Massa Jenis } \\
\left(\mathrm{kg} / \mathrm{m}^{3}\right)\end{array}$ & $\begin{array}{c}\text { Modulus } \\
\text { Elastisitas }(\mathrm{MPa})\end{array}$ & $\begin{array}{c}\text { Poisson } \\
\text { Ratio }\end{array}$ \\
\hline Baja & 7850 & 206.000 & 0,3 \\
FRPU & 1098 & 901,95 & 0,36 \\
\hline
\end{tabular}

Perhitungan modulus perlu dilakukan karena nilai modulus kapal diperlukan dalam perhitungan ketebalan faceplate dan core dari material sandwich. Perhitungan ketebalan faceplate dan core dilakukan menggunakan standard Lloyd's Register (Lloyd's Register, 2020). Tebal faceplate dan core berpatokan pada nilai strength index (R), dimana nilai $\mathrm{R}$ harus kurang dari 1 (Lloyd's Register, 2020). Perhitungan pembebanan pada struktur sisi lambung kapal tanker menggunakan standard Bureau Veritas (2020). Nilai pembebanan dihitung menggunakan rumus still water pressure yang dapat dihitung menggunakan Persamaan (1).

$$
P=\rho g z
$$

Dimana $\rho$ adalah massa jenis air laut $\left(\mathrm{kg} / \mathrm{m}^{3}\right), \mathrm{g}$ adalah percepatan gravitasi $\left(\mathrm{kg} / \mathrm{m}^{2}\right)$, dan $\mathrm{z}$ adalah titik kedalaman $(\mathrm{m})$.

Rumus pembebanan air tenang atau still water pressure diperoleh dari penurunan Hukum Archimedes dimana gaya tekan air sama dengan massa jenis air dikali gravitasi dan dikali kedalaman benda. Semakin dalam titik berat pelat maka semakin tinggi beban yang dikenakan. Pengambilan nilai titik z dilakukan setiap jarak 1 meter sehingga nilai pembebanan lebih presisi. Nilai pembebanan tersebut di-input ke software elemen hingga dan aplikasi dari pembebanan tersebut divisualisasikan dalam bentuk arah panah seperti pada Gambar 1. 

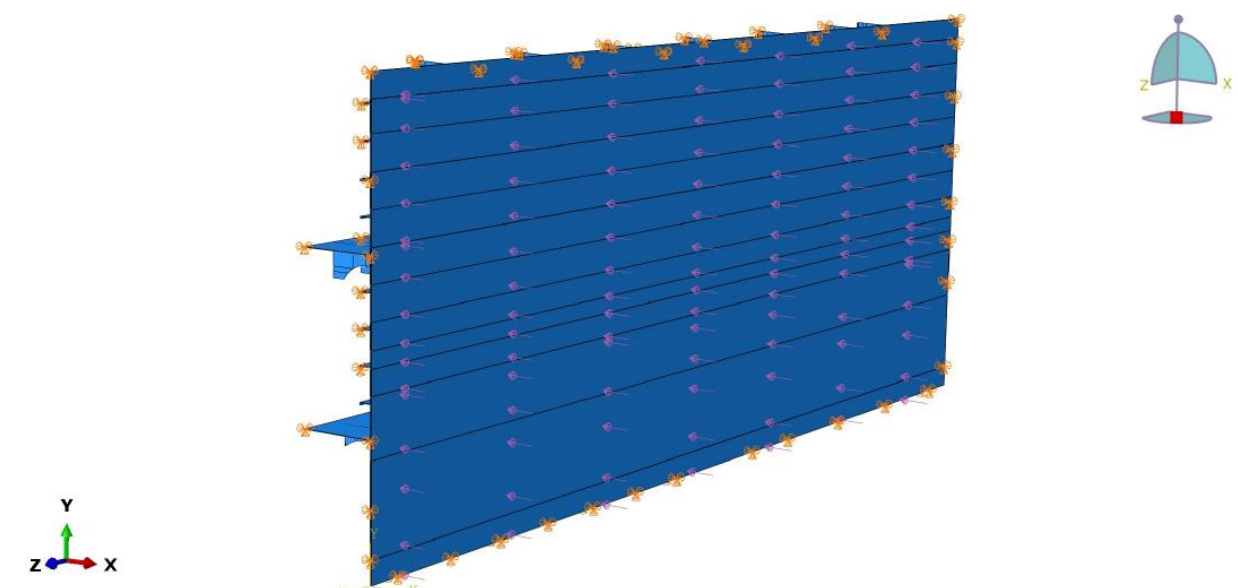

Gambar 1. Pembebanan model struktur lambung

Kondisi batas berupa jepit telah digunakan pada bagian sisi dari struktur. Model numerik konstruksi lambung kapal memiliki relatif kompleks karena tiga side longitudinal memiliki ukuran yang berbeda dan web frame dipisahkan oleh stringer, sehingga pemodelan harus dilakukan secara terpisah. Gambar 2 menunjukkan komponen-komponen pada struktur lambung yang telah digabung.

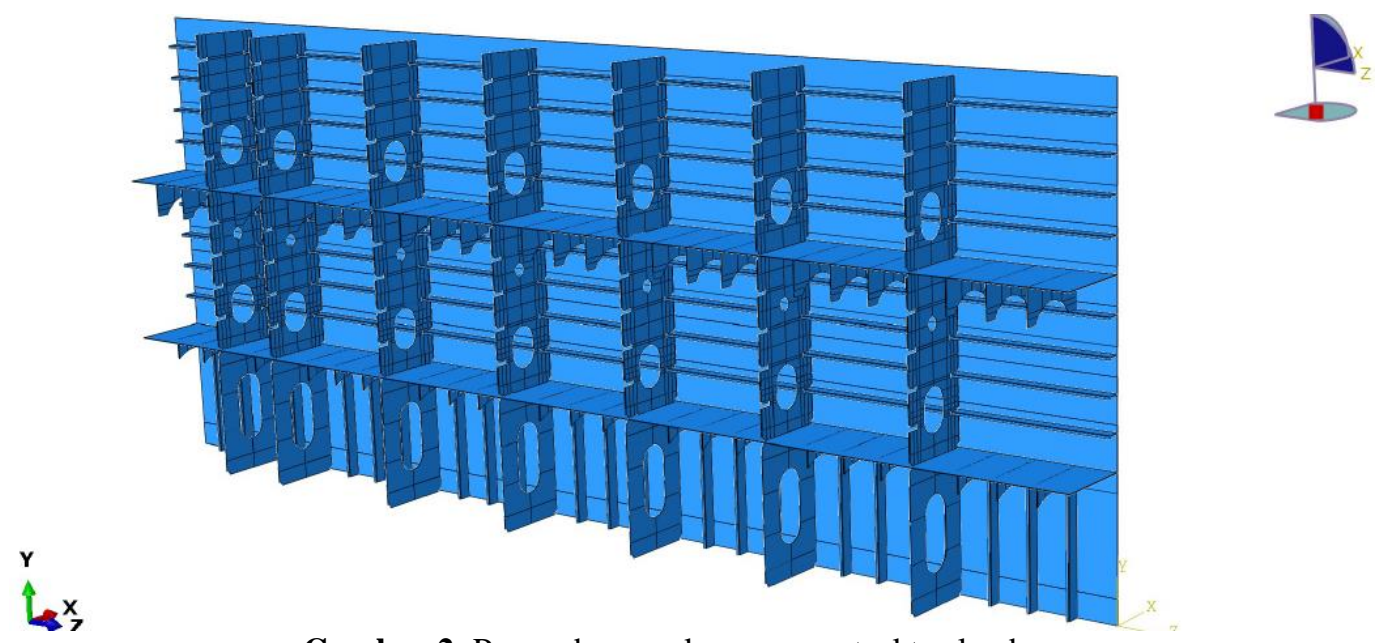

Gambar 2. Penggabungan komponen struktur lambung

Meshing merupakan proses partisi suatu model menjadi beberapa elemen yang lebih kecil. Semakin kecil ukuran mesh maka semakin banyak jumlah elemen yang tercipta. Terdapat beberapa metode dalam pembuatan elemen mesh, diantaranya adalah hexahedral, tetrahedral, ataupun campuran antara keduanya. Teknik dalam pembentukan mesh dengan bentuk hexahedral pun terdapat beberapa jenis seperti structured, sweep, dan bottom-up. Pada penelitian ini, hexahedral structured mesh telah digunakan sebagai teknik dalam pembentukan elemen mesh. Metode meshing ini memiliki hasil yang cocok dalam analisis numerik, karena hasil mesh akan lebih rapi dan lebih terstruktur sehingga output akan lebih konvergen dan lebih presisi.

Penentuan ukuran mesh dilakukan menggunakan studi konvergensi untuk mendapatkan ukuran dan jumlah elemen yang optimal. Selisih antara output percobaan kedua harus kurang dari $2 \%$ jika dibandingkan dengan percobaan yang pertama (Ismail, 2021a). Kriteria studi konvergensi yang telah dilakukan pada riset ini lebih baik daripada kriteria 5\% yang digunakan oleh (Wang et al., 2014). 


\section{HASIL DAN PEMBAHASAN}

Analisis perbandingan struktur lambung konvensional dan struktur lambung menggunakan material sandwich dilakukan untuk mengkaji nilai tegangan and berat struktur yang disimulasikan dengan metode elemen hingga. Modulus penampang kapal tanker adalah sebesar 18.808.332,18 $\mathrm{cm}^{3}$. Nilai modulus tersebut digunakan sebagai input untuk menentukan tebal faceplate dan core dari material sandwich, dimana tebal faceplate terkecil adalah $3 \mathrm{~mm}$ berdasarkan Lloyd's Register (2020). Beberapa tebal faceplate dianalisis sesuai panduan Lloyd's Register (2020) mulai dari 3 $\mathrm{mm}-6 \mathrm{~mm}$. Berdasarkan Tabel 3, tebal faceplate sebesar $4 \mathrm{~mm}$ dan tebal core sebesar $20 \mathrm{~mm}$ dipilih karena konfigurasi tersebut memiliki strength index (R) lebih kecil dari 1 dan memiliki berat yang paling rendah.

Tabel 3. Strength index (R) dengan variasi ketebalan faceplate

\begin{tabular}{ccccc}
\hline $\begin{array}{c}\text { Tebal Core } \\
(\mathrm{mm})\end{array}$ & $\begin{array}{c}\text { Tebal Faceplate } \\
\text { Atas }(\mathrm{mm})\end{array}$ & $\begin{array}{c}\text { Tebal Faceplate } \\
\text { Bawah }(\mathrm{mm})\end{array}$ & $\begin{array}{c}\text { Strength } \\
\text { Index }\end{array}$ & Keputusan \\
\hline 20 & 3 & 3 & 1,09 & Ditolak \\
20 & 4 & 4 & 0,8 & Diterima \\
20 & 5 & 5 & 0,63 & Diterima \\
20 & 6 & 6 & 0,51 & Diterima \\
\hline
\end{tabular}

Semakin kecil ukuran elemen mesh maka jumlah elemen mesh akan semakin banyak. Jumlah elemen yang banyak akan membuat analisis numerik semakin presisi. Akan tetapi, tingginya jumlah elemen mesh akan menambah beban kerja dari hardware dan meningkatkan durasi proses running dari sebuah analisis. Oleh karena itu, perlu dilakukan studi konvergensi (sering juga disebut sebagai analisis grid independence) untuk mencari jumlah elemen mesh yang optimal dimana hasil yang diperoleh mendekati hasil sebenarnya dengan jumlah mesh yang sesedikit mungkin. Selisih antara output percobaan kedua harus kurang dari $2 \%$ jika dibandingkan dengan percobaan yang pertama (Ismail, 2021a).

Pada model sisi konvensional, konvergensi model telah terjadi pada jumlah elemen dua juta tujuh ratus ribu. Sedangkan pada model sisi sandwich, model telah konvergen pada jumlah elemen sekitar empat juta tiga ratus ribu seperti pada Gambar 3. Jumlah elemen mesh yang telah diperoleh tersebut akan dijadikan patokan dalam melakukan analisis numerik pada model konvensional dan sandwich. Struktur yang kompleks dan tebanya konfigurasi pelat sandwich membuat model ini memiliki kesulitan dalam mendapatkan nilai konvergensinya.

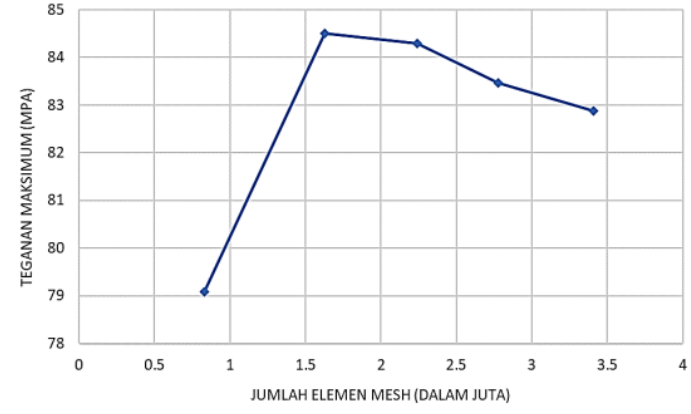

(a)

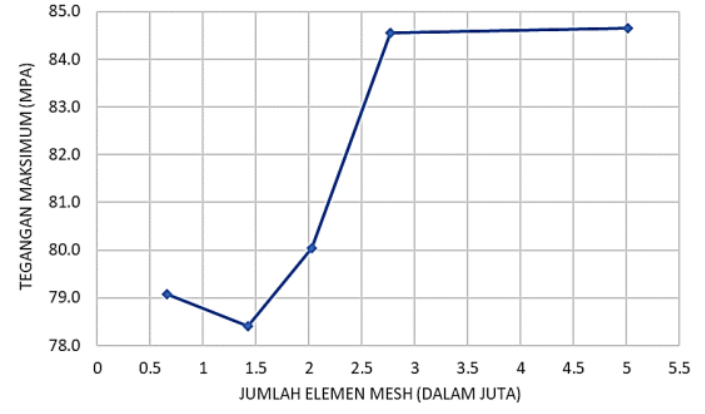

(b)

Gambar 3. Studi konvergensi (a) model lambung konvensional, (b) model lambung sandwich

Tegangan merupakan gaya yang bekerja pada suatu permukaan dengan suatu satuan luas. Pada model lambung konvensional tegangan maksimum yang terjadi adalah 83,5 MPa dan lokasi konsentrasi tegangan terjadi di pembujur sisi bagian bawah, seperti terlihat pada Gambar 4. Sedangkan konsentrasi tegangan pada model sandwich dapat dilihat pada Gambar 5 dengan tegangan maksimum sebesar $84,5 \mathrm{MPa}$. Peningkatan tegangan yang terjadi akibat penerapan 
sandwich pada bagian lambung kapal sangat rendah yaitu sebesar 1,2\%. Namun demikian, baik struktur lambung konvensional maupun struktur lambung material sandwich masih memenuhi kriteria untuk dapat diterapkan pada struktur lambung kapal tanker, karena kedua model memiliki tegangan jauh dibawah batas tegangan yang diizinkan yaitu 235 MPa (Lloyd's Register, 2014). Hasil penelitian yang sama juga diperoleh pada penelitian lain (Brooking \& Kennedy, 2004), bahwa struktur kapal dengan material sandwich memiliki tegangan yang lebih rendah dari kriteria tegangan kapal.

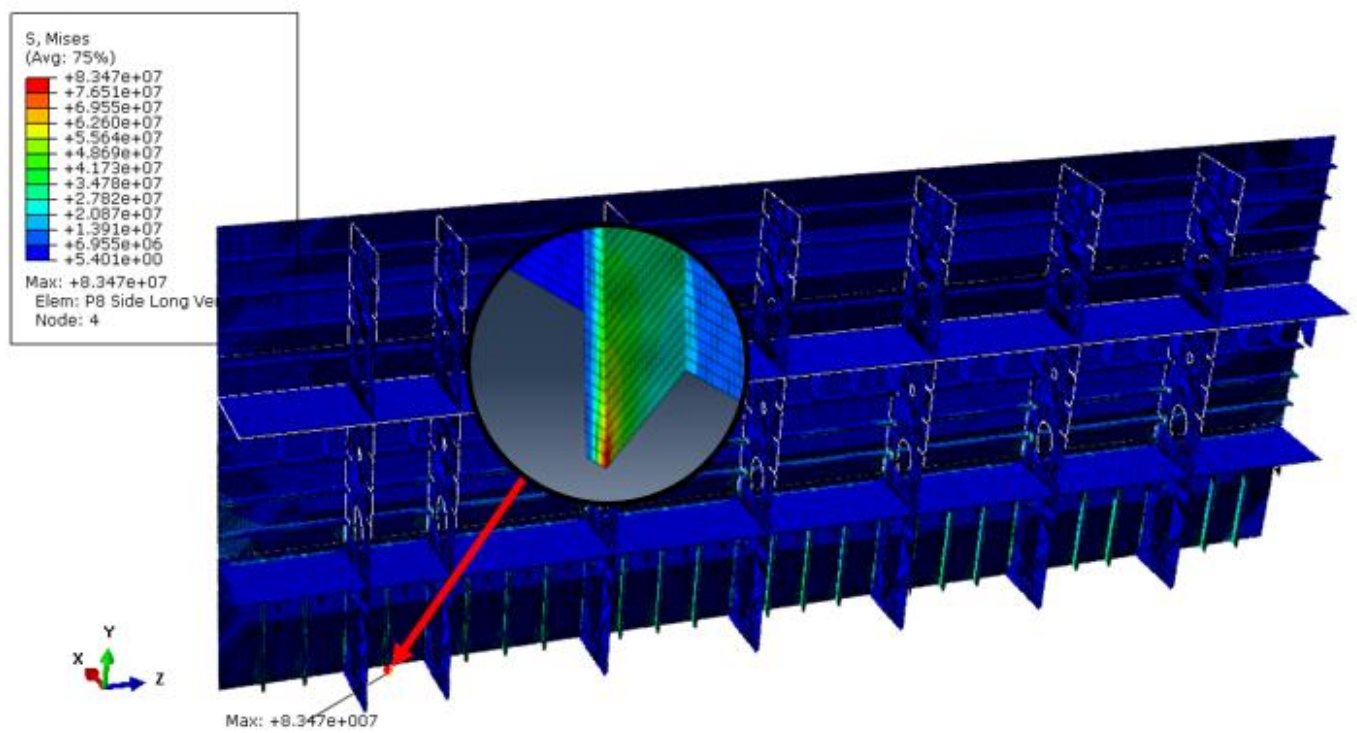

Gambar 4. Distribusi tegangan dan lokasi konsentrasi tegangan pada model lambung konvensional

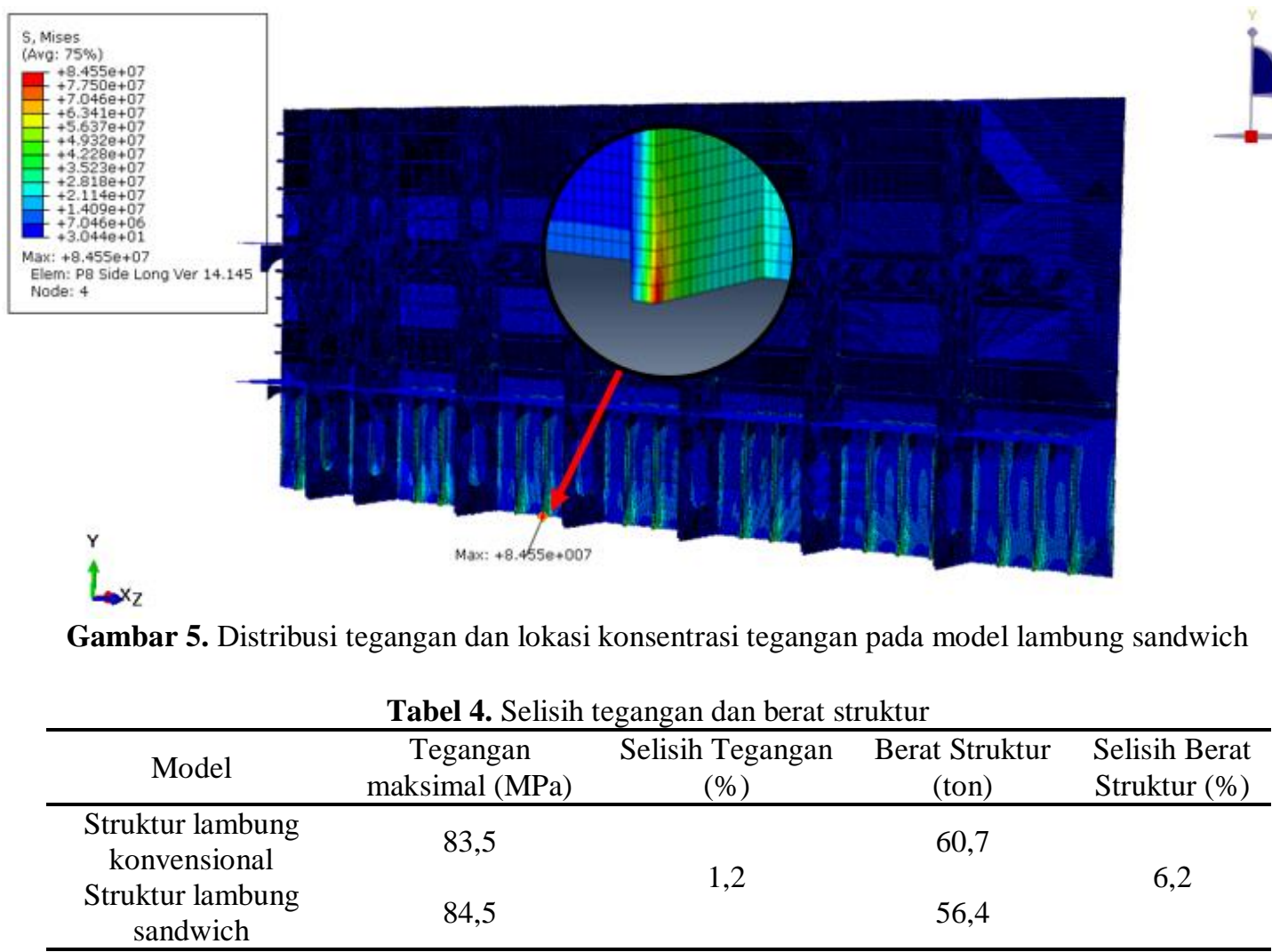


Sisi positif lain yang cukup signifikan dari penerapan material sandwich pada struktur lambung adalah adanya pengurangan berat. Berat dari struktur lambung konvensional adalah 60,7 ton, sementara berat dari struktur lambung material sandwich adalah 56,4 ton. Jadi terdapat pengurangan berat sebesar 3,7 ton atau $6,2 \%$, sebagaimana dapat dilihat pada Tabel 4 . Penerapan material sandwich dapat mengurangi berat konstruksi kapal secara keseluruhan sehingga kapal dapat mengangkut muatan (payload) lebih banyak dan membuat operasional kapal lebih ekonomis. Peningkatan daya angkut kapal tanker sebesar 3,7 ton sebagai manfaat dari aplikasi material sandwich adalah sesuatu yang cukup menarik bagi dunia industri kapal tanker kedepannya. Kajian ekonomis penerapan material sandwich pada struktur kapal perlu diteliti lebih lanjut kedepannya. Material sandwich dapat digunakan pada sistem replating (Djumiati et al., 2021) atau pembuatan struktur baru pada bagian kapal lainnya seperti, geladak, bangunan atas, atau bagian lainnya.

\section{KESIMPULAN}

Kajian teknis berupa analisis kekuatan dan berat struktur antara lambung konvensional dan lambung dengan material sandwich telah dilakukan pada kapal tanker 17.500 DWT. Berdasarkan penelitian ini, penerapan material sandwich pada struktur lambung menghasilkan karakteristik struktur yang unik yaitu dihasilkan kenaikan tegangan yang sangat kecil tetapi diperoleh pengurangan berat struktur yang cukup besar dibandingkan dengan struktur lambung kapal konvensional.

Penerapan material sandwich dapat mengurangi berat konstruksi kapal, sehingga tanker dapat mengangkut muatan lebih banyak dan operasional kapal dalam sekali perjalanan akan lebih ekonomis. Dengan demikian, pengembangan material ringan kapal diharapkan mampu menunjang kualitas operasional kapal dan diharapkan mampu meningkatkan daya saing kapal tanker nasional. Meskipun lebih ringan, struktur dengan material sandwich tetap memenuhi kriteria tegangan dengan nilai yang meyakinkan. Tegangan maksimum struktur lambung dengan material sandwich adalah sebesar 84,5 MPa, sehingga struktur yang dikembangkan layak untuk digunakan pada bagian lambung kapal. Material sandwich dapat digunakan pada sistem replating pada geladak, bangunan atas atau bagian struktur lain dari kapal. Riset ini memiliki keterbatasan, yaitu hanya mengkaji penerapan material sandwich pada bagian lambung, bagian kapal lain yang cukup menarik untuk diaplikasikan material sandwich ialah geladak dan bangunan atas. Riset berkelanjutan perlu juga dilakukan untuk mengkaji manfaat ekonomis dan manfaat lain dari penerapan material sandwich, termasuk analisis penerapannya pada struktur lepas pantai lainnya.

\section{DAFTAR PUSTAKA}

Ardhyananta, H., Sari, E. N., Wicaksono, S. T., Ismail, H., Tuswan \& Ismail, A. (2019). Characterization of vinyl ester bio-resin for core material sandwich panel construction of ship structure application: Effect of palm oil and sesame oil. AIP Conference Proceedings, 2202, 020051. https://doi.org/10.1063/1.5141664

Ariesta, R. C., Zubaydi, A., Ismail, A. \& Al-Syachri, M. Z. (2021a). Identification of damage in a ship hull sandwich plate by natural frequency. IOP Conference Series: Materials Science and Engineering, 1034(1), 012012. https://doi.org/10.1088/1757899X/1034/1/012012

Ariesta, R. C., Zubaydi, A., Ismail, A. \& Tuswan, T. (2021b). Damage evaluation of sandwich material on side plate hull using experimental modal analysis. Materials Today: Proceedings, 47, 2310-2314.

Brooking, M., \& Kennedy, S. (2004). The Performance, Safety and Production Benefits of SPS Structures for Double Hull Tankers. Proceedings of the RINA Conference on Double Hull Tankers, 1-2.

Bureau Veritas. (2020). Rules for The Classification of Steel Ships, Paris, Perancis. Bureau Veritas.

Djumiati, A., Zubaydi, A., Putra, W. H. A. \& Ismail, A. (2021). The effect of ship replating welding process on floating conditions against strength value. IOP Conference Series: 
Materials Science and Engineering, 1034(1), 012098. https://doi.org/10.1088/1757899X/1034/1/012098

Ismail, A., Zubaydi, A., Budipriyanto, A., \& Yudiono. (2018). Damage identification of the sandwich plate having core from rice husk-epoxy for ship deck structure. Proceedings of the 3rd International Conference on Marine Technology - SENTA, 112-118. https://doi.org/10.5220/0008543301120118

Ismail, A., Zubaydi, A., Piscesa, B., Ariesta, R.C. \& Tuswan. (2020). Vibration-based damage identification for ship sandwich plate using finite element method. Open Engineering, 10(1), 744-752. https://doi.org/10.1515/eng-2020-0086

Ismail, A., Zubaydi, A., Piscesa, B., Ariesta, R.C. \& Tuswan. (2021a). Study of sandwich panel application on side hull of crude oil tanker. Journal of Applied Engineering Science, 1-9. https://doi.org/10.5937/jaes0-30373

Ismail, A., Zubaydi, A., Piscesa, B., Panangian, E., Ariesta, R. C. \& Tuswan, T. (2021b). A strength analysis of conventional and sandwich plate deck using finite element method. IOP Conference Series: Materials Science and Engineering, 1034(1), 012026. https://doi.org/10.1088/1757-899X/1034/1/012026

Ismail, A., Zubaydi, A., Piscesa, B., Panangian, E., Ariesta, R. C. \& Tuswan, T. (2021c). A comparative study of conventional and sandwich plate side-shell using finite element method. IOP Conference Series: Materials Science and Engineering, 1034(1), 012027. https://doi.org/10.1088/1757-899X/1034/1/012027

Lloyd's Register. (2014). Rules for the Manufacture, Testing and Certification of Materials, London, United Kingdom. Lloyd's Register Group Limited.

Lloyd's Register. (2020). Rules for the Application of Sandwich Panel Construction to Ship Structure, London, United Kingdom. Lloyd's Register Group Limited.

Mohamed, M., Anandan, S., Huo, Z., Birman, V., Volz, J., \& Chandrashekhara, K. (2015). Manufacturing and Characterization of Polyurethane Based Sandwich Composite Structures. Composite Structures, 123, 169-179.

Ramakrishnan, K. V. \& Kumar, P. G. S. (2016). Applications of Sandwich Plate System for Ship Structures. IOSR Journal of Mechanical and Civil Engineering, 83-90.

Sujiatanti, S. H., Zubaydi, A., Budipriyanto, A. (2018). Finite Element Analysis of Ship Deck Sandwich Panel. Applied Mechanics and Materials, 874, 134-139.

Tuswan, T., Zubaydi, A., Piscesa, B., Ismail, A., Ariesta, R.C., Ilham, M. F. \& Mualim, F. I. (2021a). Influence of application of sandwich panel on static and dynamic behaviour of ferry ro-ro ramp door. Journal of Applied Engineering Science, 19(1), 208-216. https://doi.org/10.5937/jaes0-27708

Tuswan, T., Zubaydi, A., Piscesa, B., Sari, E. N. \& Ismail, A. (2021b). Core sandwich material development based on vinyl ester bioresin for ship structure application. IOP Conference Series: Materials Science and Engineering, 1034(1), 012152. https://doi.org/10.1088/1757-899X/1034/1/012152

Tuswan, T., Zubaydi, A., Piscesa, B., Ismail, A., Ariesta, R. C. \& Prabowo, A. R. (2022). A numerical evaluation on nonlinear dynamic response of sandwich plates with partially rectangular skin/core debonding. Curved and Layered Structures, 9(1), 25-39. https://doi.org/10.1515/cls-2022-0003

Wang, I. T. (2014). Numerical and experimental verification of finite element mesh convergence under explosion loading. Journal of Vibroengineering, 16(4), 1786-1798.

Yang, J. S., Ma, L., Schmidt, R., Qi, G., Schröder, K. U., Xiong, J., \& Wu, L. Z. (2016). Hybrid Lightweight Composite Pyramidal Truss Sandwich Panels with High Damping and Stiffness Efficiency. Composite Structures, 148, 85-96. 